\title{
Täysivaltaisuus kasvatustavoitteena?
}

\section{Nykyisen kasvatustieteen vaarasta kadottaa subjektinsa}

\begin{abstract}
Matthies Jürgen 1989. Täysivaltaisuus kasvatustavoitteena? Aikuiskasvatus 9, 1. 19-23.
- Artikkelin ensimmäinen osa käsittelee kysymystä, missä määrin moderni kasvatustiede on tiettyjen tutkimussuuntaustensa kautta muuttunut utilitaristiseksi instrumenttiopiksi. Voidaan epäillä, että yksittäistä koulutettavaa ei enää nähdä subjektina, vaan häntä käsitellään objektina, kun itsenäisyyttä korostavat kasvatustavoitteet alistetaan yhä enemmän $\mathrm{mm}$. teknistaloudelliselle intressille. Artikkelin toisessa osassa pyritään osoittamaan Marcusen kirjoitusten pohjalta, mihin oppilaan/opiskelijan ja yleensä ihmisen esineellistäminen jo koulutusjärjestelmissä ja kasvatustieteissä voi johtaa. Tässä yhteydessä selvitetään muutamien esimerkkien kautta yksiulotteisuuden käsitettä. Lopuksi analysoidaan Marcusen pedagogista ajattelua ja sovelletaan sitä nykyiseen kasvatustodellisuuteen.
\end{abstract}

Keskustelu sivistyksen ja koulutuksen sisällöllisestä tavoitteenasettelusta ei liene koskaan epäajankohtaista (esim. Salonen 1987). Sitä tärkeämpää se on, mitä dynaamisemmin reformeja ajetaan läpi. Aikamme kasvatustieteellisten julkaisujen enemmistö käsittelee kysymyksiä, kuinka nykyistä kasvatusjärjestelmää voitaisiin laajentaa ja kehittää, kuinka sen menetelmät voitaisiin saada toimivimmiksi ja menestyksekkäämmiksi, kuinka opetustavoitteet voitaisiin määritellä ja saavuttaa tarkemmin. Kun nähdään vaivaa olemassa olevan sivistysjärjestelmän tehostamiseksi, torjutaan usein kysymys koko kasvatuksen tavoitteista, luonteesta ja seurauksista.

Kun tässä yhteydessä puhuu subjektin katoamisesta tai jopa hävittämisestä, voi joutua epäillyksi tietämättömyydestä kasvatustieteen päämääristä. Sillä onhan yhtenä sen päätavoitteena tukea ihmisen itsenäisyyttä ja riippumattomuutta. Oman käsityksensä mukaan kasvatustiede jatkaa täten historiallista tehtäväänsä, joka alkoi Sokrateesta ja Platonista ja on jatkunut Rousseaun, Kantin ja Pestalozzin kautta nykypäivään saakka. Mutta missä määrin subjektin itsemääräytymisen tavoite voi toteutua, kun nykyistä kasvatustiedettä leimaavat erilaiset ristiriitaiset motiivit? Yksi niistä on teknistaloudellinen intressi. Siitä kertoo esimerkiksi meneillään olevaan yliopistojen hallinnonuudistukseen sisältyvä tulosvastuuajattelu. Sen mukaan kasvatuksen ja kasvatustieteen tulee olla mahdollisimman tehokasta. Sen tuotta- man tuotteen - koulutetun ihmisen - tulee toimia mahdollisimman hyvin. Kun kasvatustieteen on mahdollista osoittaa toiminnallaan olevansa yhteiskunnallisesti ja poliittisesti hyödyllistä, se hankkii samalla itselleen julkista arvostusta. Tätä arvostusta tukee myös luonnontieteiden edistyksellisyyden ja ihanteiden mukaan kehittynyt metodi. Kasvatustieteenkin tulee olla arvovapaata, jotta sen tulokset olisivat subjektista riippumatta testattavissa; vain objektiivisesti mitattava ja kvantifioitava on voimassa.

Ei voi olla huomaamatta läheistä yhteyttä taloudellisen hyväksikäytön intressin ja modernin kasvatustieteen toimintatavan välillä. Kasvatustieteestä itsestäänkin tulee tuotantovoima, jossa vallan diskurssi ja performatiivisuus hallitsevat. Valtio ja yritykset eivät enää tarvitse idealistisia tai humanistisia legitimaatioita; "oppineita, tekniikkoja ja koneistoja ei osteta totuuden selvittämiseksi, vaan vallan laajentamiseksi" (Lyotard 1986, 135). Teknistaloudellinen intressi määrää pitkälle modemeja tutkimussuuntauksia, se näkyy koulutuspolitiikassa, se ohjaa koulunuudistuksia ja opettajankoulutusta. Ikäänkuin siihen sitoutunut tutkimus antaisi pedagogille välineet saada käytäntö hallintaansa.

Hermann Giesecke päätyy seuraavaan arvioon Saksan Liittotasavallassa paljon keskustelua aiheuttaneessa teoksessaan "Das Ende der Erziehung" (Kasvatuksen loppu): Kasvatustieteellistä tutkimusta ja siitä johdettuja toiminta- 
ohjeita muokataan yhä vähemmän lapsen ja hänen tarpeidensa näkökulmasta (vrt. myös Alanen 1988). Näiden tilalle on tullut manipuloivan kasvattajan näkökulma. Manipuloivat tendenssit eivät missään tapauksessa rajoitu vain kognitiiviselle tasolle oppimistavoitekonstruktioihin, jotka eivät pidä lasta juuri muuna kuin oppimiskoneena. Sen lisäksi on tarkoitus koota koko emotionaalinen ja sosiaalinen taso opettajan manipuloivaan otteeseen soveltamalla ryhmädynaamista ja psykoanalyyttista tietämystä ja menetelmiä. (Giesecke 1987, 59-).

Niinpä pedagogin täytyy objektiivisen lainalaisuuden noudattamisen nimissä yrittää sulkea kasvatustapahtuman ulkopuolelle nk. subjektiiviset tekijät, erityisesti arvosidonnaiset käsitykset, jotta toivottu vaikutus voitaisiin ennakoida selkeämmin ja saavuttaa suuremmalla tarkkuudella. Myös oppimistutkimus seuraa usein tätä tavoitetta. Eihän ole lainkaan sattuma, että kokeellisia tutkimuksia on tehty ensin koirilla ja rotilla siinä toivossa, että subjektiivisten tekijöiden vaikutus voitaisiin pitää mahdollisimman pienenä. On onnistuttava yhä paremmin jäljittämään ne lainalaisuudet, joiden mukaan käyttäytymistä ja lopulta myös tietoisuutta voidaan ohjata.

Kuten moderni kasvatustiede on korvannut kysymyksen totuudesta, kriittisestä itsereflektiosta, legitimaatiosta ja merkityksestä ottamalla tilalle kysymyksen tehokkuudesta, samoin ei myöskään pedagoginen ajattelu pyri enää "humaanin ihmisen kukoistukseen" (Pestalozzi), vaan yhteiskunnan ja politiikan määrittelemään funktionaaliseen käyttökelpoisuuteen. Tällä tavoin ymmärretyllä tieteellä on enää vain operatiivinen arvo. Sen seurauksena tiede on ottanut käyttöön uuden kumoamiskriteerin (Falsifikationskriterium): jokin on totta niin kauan, kuin se toimii ja kun se on operationaalisesti luotettava.

Tieteen itseymmärryksen muuttuminen on aiheuttanut selvän muutoksen myös käytäntöön. Oppiminen ei ole itsereflektiota, kokonaisuuksien läpikäymistä ja työstämistä. Se on pikemminkin sellaisen informaation tallentamista ja tulostamista, jota voidaan käyttää suunniteltuun toimintaan. Opettaminen ei ole oppilaan liittämistä osalliseksi totuudenetsinnästä, vaan taitavaa strategiaa, jolla oppilas saadaan ahmimaan mahdollisimman paljon informaatiota mahdollisimman lyhyessä ajassa. Parhaiten tämä kuvastuu eräissä yliopistojen opetusohjelmien malleissa (Matthies 1988).

Tiede redusoi itsensä kysymykseksi soveltuvista menetelmistä. Se alistaa järjen ottamalla siltä vapauden ja itsemääräytyvyyden, eli tiede itse asiassa luopuu siitä, mihin sen arvovapauden katsotaan perustuvan. Siksi on naivia hä- mäystä uskoa, että kasvatustiede pelkkänä välineoppina (Instrumentenlehre) voisi pestä kätensä omien päämääriensä suhteen.

Kasvatustieteen redusoituminen kysymykseksi välineistä ja menetelmistä nostaa tehokkuusvaatimuksen hallitsevaksi ohjesäännöksi. Tehokkuusvaatimus sisältää samalla kätketyn normatiivisuuden: holhouksenalaisuuden, sopeutumisen, opportunismin ja kantaaottamattomuuden normin. Se ajaa luopumaan omasta tunnollisuudesta ja alistumaan Isonveljen holhoavan järjen määräykseen.

Kasvatus ei ole enää johdattelua periaatteista kiinni pitämiseen tai sitoutumiseen, vaan strategiaa, jolla tuotetaan toivottua ja käyttökelpoista käyttäytymistä. Siinä ei kysytä kriittistä tietoisuutta, vaan kvalifikaatioita, joiden hallitseminen on tarpeen tietyissä yhteiskunnallisissa asemissa ja funktioissa.

Kun opettaminen mitattavan tehokkuuden nimissä redusoituu pääasiallisesti informaation tallentamiseksi ja kyselyksi, ei voida enää perätä sen merkitystä tai perusteita. Paitsi että siihen kuluisi turhaan aikaa, se myös asettaisi koko oppimisprosessin - tehokkaan keräilyn ja tallentamisen - kyseenalaiseksi. Ajattelun pätevyys ja johdonmukaisuus subjektin kriittisen potentiaalin osoituksina olisivat vain esteinä. Sen sijaan on tuettava kykyä kaksinaisajatteluun (Zwiedenkens), jota Orwellin mukaan Isoveli odottaa vuonna 1984 alaisiltaan (Orwell 1980). Kaksinaisajattelu nimittäin sulkee pois kyvyn kriittisyyteen. On mahdollista, että kasvatustiede B.F. Skinnerin ohjelmaa seuratessaan (Skinner 1973) ei enää kysele omia päämääriään, vaan alistuu etsimään välineitä, joilla valtion, talouden, puoluepolitiikan tai ideologioiden määräämiä päämääriä toteutetaan. Kasvatustieteen on toimittava yleiseksi mittapuuksi korotetun tehokkuusvaatimusten ja omien toimenpiteidensä vaikuttavuuden nimissä. Silloin kasvatustieteen täytyy kieltää haltuunsa uskotulta subjektilta hänelle suunniteltujjen tavoitteiden arvioiminen tai kriittisten kysymysten tekeminen. Nk. oppimisen kannalta ei ole mielekästä tai rakentavaa selvittää infoŕmaation totuusarvoa. Samoin ei myöskään ole manipuloidun käyttäytymisen kannalta merkittävää tai toivottavaa pohtia käyttäytymisen eettistä sisältöä.

Tiedon ja informaation tallentaminen ei ole tulosta itse kunkin suorittamasta totuusarvon tutkimisesta, eikä käyttäytyminen ole seurausta itse kunkin sitoutumisesta valitsemaansa eettiseen vaatimukseen, vaan molemmat ovat reaktioita tavoitteellisiin ärsykkeisiin. Näiden ärsykkeiden vaikutus mahdollistuu vasta sitten, kun subjektin autonomian synnyttämä järjellisyysperiaate on hävinnyt. Silloin ulkopuolinen järki (Fremde Vernunft) osoittaa subjektille, mitä hänen on pidettävä totena tallentaakseen sen 
muistiinsa; Mitä hänen on pidettävä oikeana, ohjatakseen käyttäytymistään sen mukaan.

Juuri tässä kiteytyvät epäitsenäisyys ja esineellistyminen - tai jopa subjektin katoaminen, joista kasvatus muodollisessa tavoitteenasettelussaan on huolestunut. Kasvatus ei perustukaan silloin omaan käytännölliseen järkeensä, oman yhteisön ja tradition dialogisessa kontekstissa kehittyneeseen tietämykseen, vaan valtaa käyttäviin, asemansa itse hankkineisiin holhoajiin eli heihin, jotka uskovat edustavansa julkista mielipidettä.

Tähänastisessa tarkastelussa on pyritty kuvaamaan kriittistä teoriaa vailla olevan kasvatustieteen luonnetta ja sitä, mihin se voi johtaa. Seuraavassa keskitytään tutkimaan teoreettista mallia, joka voisi välittää hyödyllisiä ajattelun virikkeitä yksilön epäitsenäistämisen ja välineellistämisen välttämiseksi ja näiden tendenssien tulkitsemiseksi.

Vaikka filosofi Herbert Marcusen teollisuusyhteiskuntaa käsittelevät tekstit ovatkin jo parikymmentä vuotta vanhoja, niiden sisältö on kasvatustieteiden nykytilanteen analyysin välineenä hyvinkin ajankohtainen.

Marcuse puhuu yhteiskunnan yksiulotteisesta rationaliteetista, joka ei salli vaihtoehtoja, vaan reflektoi empiiris-analyyttisesti vain olemassaolevaa. Se estää aidon edistyksen, uudet tavoitteet ja vaihtoehdot. Marcusen kuvaama rationaliteetti on kyllä osittain loogista, jos ajatellaan asiaa teknisen hyödyntämisen kannalta, mutta se on kokonaisuutena muuttunut kuitenkin irrationaaliseksi konstruktioksi, teknis-taloudelliseksi apparaatiksi, joka alentaa ihmisen vain toimintansa kohteeksi.

\section{Esineellistyminen}

Marcuse tunnistaa vallankäyttöä (Herrschaft) kaikkialla, missä yksilöt eivät toimi autonomisesti, siis eivät ohjaa toimintaansa oman harkintansa pohjalta tekemiensä ratkaisujen mukaan. "Valtaa käytetään kaikkialla, missä yksilön tavoitteet ja päämäärät, sekä niihin pyrkimisen ja niiden saavuttamisen keinot ovat ennalta annettuja, ja yksilö toteuttaa niitä annettuina. Valtaa voivat käyttää ihmiset, luonto tai esineet. Se voi olla sisäistettyä, yksilön itse itseensä toteuttamaa ja se voi esiintyä autonomian muodossa" (Marcuse 1968, 6).

Vallankäytön käsitteen laajuus selittyy sillä, että ihmisen aseistautuminen luontoa vastaan - eli tekninen luonnonhallinta - kääntyykin ihmistä itseään vastaan. Alkujaan ihminen on käyttänyt tekniikkaa avukseen, nyt siitä on tullut itsetarkoitus. Ihmisen alkuperäinen vallankäyttö teknistä aparaattia kohtaan on kääntynyt päinvastaiseksi, ihmisestä subjektina on tullut objekti.
Marcuse pyrkii selittämään Freudin kulttuurikritiikin kautta koko kulttuuriin nivoutunutta ihmisen objektivoitumista. Freud ymmärtää kulttuurimme prosessina, joka tukee elämää taistelussa kuolemaa vastaan (Freud 1952, 419-). Päätehtävänä on taltuttaa kuolemanvietti, joka ilmenee ennenkaikkea hillittömissä agressioissa. Kulttuurisen kokonaisuuden kautta yksilölle sisäistetään Yliminä, jonka tehtävänä on taltuttaa viettiä torjumalla se. Siten yksilössä itsessään on kulttuurin säätelevä prinsiippi. Yksilön sinänsä autonomisilta näyttävät tarpeet ovatkin aikoja sitten kulloisenkin vallitsevan kulttuurimuodon mukaan muokkautuneita vääriä tai ei-todellisia tarpeita. Näillä "väärillä tarpeilla" on "yhteiskunnallinen sisältö ja yhteiskunnallinen funktio, jotka määräytyvät ulkoisen vallan mukaan, johon yksilöllä ei ole vaikutusta; näiden tarpeiden kehittyminen ja tyydyttäminen on epäitsenäistä" (Marcuse 1967, 25). Marcusen nyky-yhteiskuntaan viittaavan teorian mukaan tarpeet ovat itsetarkoitukseksi muuttuneen teknologian tuottamia ja ne syötetään ihmiselle mainoksilla. Koska yksilö ei ole koskaan autonominen laajalle ulottuvan herruuden suhteen, hän ei myöskään voi erottaa oikein toisistaan todellisia ja vääriä tarpeita.

Teknisen aparaatin vallalle alistuneen ihmisen vapaudettomuus peittyy kuitenkin Marcusen mukaan mukavuuteen. Vapaudettomuus — ihmisen tuleminen riippuvaiseksi teknisestä edistyksestä - muuttuu ikuiseksi ja intensiiviseksi pukeutumalla monenlaisten vapauksien ja mukavuuksien muotoon tekniikan välineillä." (Marcuse 1967, 52). Tämä voi johtaa lopulta niin pitkälle, että ihmiset tunnistavat itsensä tuotteistaan, ja samaistuvat niihin. "Ihmiset tunnistavat itsensä tavaroistaan, löytävät sielunsa autostaan, stereovastaanottimistaan, keittiökoneistaan"' (Marcuse 1967, 29).

Vähitellen myös sosiaalinen kontrolli ankkuroituu riippuvuuteen esineistä. Kontrolli voi olla niin kovaa, että henkilö, joka ei osallistu tuotantoprosessiin, vaikuttaa neuroottiselta ja hullulta. Tämä kehitys edellyttää ihmistä, joka on ajattelussaan ja toimissaan yksiulotteinen, jolla ei ole todellisia vaihtoehtoja eikä pakenemismahdollisuuksia, koska hän ajattelee enää pelkästään taloudellisen tuotannon ja kulutuksen kategorioissa. Mihin yksiulotteisuus voi johtaa, on kuvattu osuvasti Ulrich Beckin kirjan "Risikogesellschaft" (Bech 1986, 1-120) ensimmäisessä osassa.

\section{Yksiuloitteisuus}

"Der eindimensionale Mensch" on Marcusen teos, jolla oli suuri vaikutus eurooppalaiseen ja amerikkalaiseen opiskelijaliikkeeseen. Yksiulotteisen ihmisen olotilan kehittyminen 
edellä kuvattuun muotoonsa on seurausta esineiden vallasta ihmisen yli. Manipuloidut tarpeet vaativat tyydytystään. Koska tarpeidentyydytys kuitenkin on yhä useampien ihmisten saatavilla tavaroiden muodossa, alkaa epäitsenäisyys näyttää autonomialta. Manipulaatio kietoutuu elämäntyyliin. Mutta koska tämä elämäntyyli näyttää mukavammalta ja edistyneemmältä aikaisempaan verrattuna, ihminen vastustaa sen kaikkea laadullista muutosta. Vain määrällinen edistys eli kasvun lisääntyminen on hyväksyttävää. "Syntyy yksiulotteisen ajattelun ja käyttäytymisen malli. Siinä torjutaan ja muokataan toisiksi sellaiset ideat, pyrkimykset ja tavoitteet, jotka ylittävät sisällöllisesti vallitsevan universumin kielen ja toiminnan. Ne määritellään uudelleen tämän universumin käsitteillä ja vallitsevan systeemin rationaliteetilla". (Marcuse 1967, 32). Uuden rationaliteetin irrationaalisuus johtuu ihmisen alistamisesta tekniselle koneistolle ja luonnonhallinnan alkuperäisen tarkoituksen unohtamisesta.

Irrationaalista yksiulotteisuutta vastaa erityinen ajattelun ja tieteellisen metodiikan muoto, nimittäin positivismin ja empirismin ylivalta. Positivismi hylkää kaiken metafyysisen ja transendentaalisen. Kun positivismin tietämys rajoittuu olevaan ja on vailla transendentaalisuutta, se ei ylitä eikä epäile mitään, mikä on vakiintunutta. Positivismilla on affirmatiivinen vaikutus, sillä "sen filosofinen kritiikki rajoittuu vain yhteiskunnan sisälle ja leimaa ei-positivistiset käsitteet pelkäksi spekulaatioksi, unelmiksi ja fantasioiksi" (Marcuse 1967, 168).

Samoin on empirismin laita. Myös siinä redusoidutaan siihen, mikä on. Vain olevaa analysoidaan ja todennetaan usein varsin kyseenalaisilla menettelytavoilla. Pohjimmiltaan siinäkin on kysymys epäkriittisestä konservatismista, joka tutkii ja reflektoi vain olemassa olevaa. Tieteellinen ajattelu ammentaa vain annettujen rajojen sisäpuolelta. Kysymys siitä, mitä voisi olla, ei pääse reflektion piiriin, koska reflektio rajoittuu vain kokemukseen (koettuun ). Tässä mielessä empirismi ja positivismi ovat yksiulotteisia ajattelun muotoja ja toimivat affirmatiivisesti.

Yksiulotteinen todellisuuskäsitys edellyttää tietynlaista ihmiskäsitystä. Sitä voidaan kuvata sanoilla riippuvaisuus, vieraantuneisuus, epäitsenäisyys ja holhouksen alaisuus eli vajaavaltaisuus (Entmündingkeit).

Yksiulotteisen ihmisen olotilaan liittyy yhä laajeneva hallinto ja byrokratia. Se on seurausta teknis-taloudellisen aparaatin eriytymisprosessista ja sen seurauksena ihmisen elämän muuttumisesta yhä monimutkaisemmaksi. Vapauden ja täysivaltaisuuden alueet kapenevat jatkuvasti, varsinkin kun hallinto näyttää tuovan mukanaan helpotuksia. "Niin kauan kuin olosuhteet pysyvät entisenlaisina, vapauden käyttöarvo pienenee. Sillä yksilöillä ei ole mitään syytä pitää kiinni itsemääräämisoikeudestaan, jos hallinnonalainen (verwaltete) elämä on mukavaa ja jopa hyvää elämää" (Marcuse 1967, 69).

Entä mitä aineksia Marcusen teoria tarjoaa kasvatustieteelliselle ajattelulle? Esimerkiksi Marcusen kuvailema yhä laajeneva ja hienojakoisempi ihmisen objektivoituminen on sovellettavissa myös kasvatustieteisiin: ihminen varsinaisena subjektina muuttuu monessa suhteessa omien luomustensa objektiksi. Tällä on myös koulutuspoliittisia seurauksia. Ihmisen sivistäminen jää yhä enemmän taka-alalle, kun koneisto asettaa koulutuksen tavoitteet ja kiristää vallankäyttöään sen toteuttamisessa. Tuloksena on koulutettu ihminen, joka ei kykene toteuttamaan kaikinpuolista yksilöllisyyttään eikä edistymään humanismin hengessä. Hän vain asettaa itsensä ja tietämyksensä tuotantoprosessin käytettäväksi. Sivistyksestä häviää sen kokonaisvaltainen, ihmistä palveleva luonne, ja se rajoittuu pelkäksi kouluttamiseksi. Tätä on Heinz J. Heydorn kuvannut kirjassaan "Über den Widerspruch von Bildung und Herrschaft" (Heydorn 1979). Koska tekniikka ja talous tarvitsevat yhä laajenevan monimutkaistumisensa vuoksi yhä enemmän spesialisteja, tulee koulutuksen olla yhä enemmän ammattisidonnaista ja siten kapea-alaisempaa. Täten Marcusen teesit voivat olla apuna nykyisten sivistyslaitosten ja koulutusmenetelmien luonteen oivaltamisessa ja niiden epäkohtien tunnistamisessa.

Lisäksi Marcusen teoria johdattelee pohtimaan uudelleen kasvatustieteiden positivismia ja empiirisiä metodeja. Niiden mukaan suuntautunut kasvatustiede lisää vaaraa, joka sisältyy pääasiallisesti empiirisiä tutkimusmenetelmiä käytettäviin teknokraattisiin toimintamalleihin. Yhteiskunta toimeksiantajana on kiinnostunut tavoitteiden tehokkaasta toteutumisesta. Voidakseen tuottaa tuloksia toimeksiannon mukaisesti on kasvatustieteen muokattava kasvatustodellisuus omien empiiristen menetelmiensä mukaiseksi. Mutta tällä tavoin kutistetuilla menetelmillä ei voida saavuttaa koko totuutta. Yhteiskunnan vallitsevia arvoja ja normeja sovelletaan sellaisenaan kritiikittä, koska tieteellinen tutkimus ei keskity niiden oikeutuksen tutkimiseen, vaan ennalta määrätyn tehtävän kasvatustieteelliseen toteuttamiseen. Tieteellisen prosessin kuluessa todettavissa olevasta todellisuudesta tuleekin normaliteetti. Siten positivismin näennäinen arvovapaus paljastuukin mitä oivallisemmaksi ideologioiden kasvualustaksi.

Johtopäätöksenä voidaan todeta, että teollisesti organisoitu kasvatustiede ei anna juurikaan toivoa yksittäiselle subjektille tai humani- 
soitumiselle. Jo nykyisen kasvatustieteen kieli paljastaa sen tendenssin. Salonen toteaa samoin, kuinka korkeakoululaitoksen kehittämislain terminologia "tehokkaine ja tuloksillisine toimintoineen" kertoo yritysmaailman periaatteiden soveltamisesta yliopistoon (Salonen 1987). Kasvatustieteissä puolestaan puhutaan strategiasta ja ohjauksesta, operationalisoimisesta ja evaluoinnista, mieleen tallentamisesta ja palauttamisesta, tulosten parantamisesta ja tehokkuudesta jne. Tutkitaan, millä organisatoris-institutionaalisilla ehdoilla, millä didaktisilla ohjelmilla ja millä opetusvälineillä koululaiset ja opiskelijat voidaan parhaiten syöttää. Millä välineillä oppimisen objektit saadaan omaksumaan mitattavaa tietoa mahdollisimman paljon mahdollisimman lyhyessä ajassa. Paras keino olisikin "tietopillerin" keksiminen.

Tämänkaltaisen tieteen, kasvatuksen, politiikan ja hallinnon systeemin seuraukset ovat tuhoisia. Ne alentavat ihmisen kohteeksi, pelkäksi funktioita sisältäväksi olioksi, jota voidaan käyttää kulloisiinkin yhteiskunnallisiin, taloudellisiin ja poliittisiin välttämättömyyksiin. Kuten postmodernit kirjoittajat ovat analysoineet (esim. Founcault 1974, 411-, Baudrillard 1982, Derrida 1985, Ferry \& Renaut 1987), luovutaan samalla ihmisestä subjektina, henkilönä, jolla on tietoisuus ja vapaus, kriittinen kompetenssi ja vastuu omista ratkaisuistaan.

Mikäli kasvatustiede ei halua tehdä itseään osasyylliseksi tähän subjektin alistamiseen ja hävittämiseen, niin sen on muutettava ajatteluaan radikaalisti. Silloin se ei voi sitoa järkeä mitattavaan ja ennakoitavaan rationaliteettiin. Kaikkea ei voida tarkastella käyttökelpoisuuden nimissä, vaan ihmisen tulee oppia tuntemaan vastuunsa tavoitteita asettavana järjellisenä olentona, jonka on itse otettava itselleen vapaus totuuden etsintään. Kasvatustieteen toiminnan tarkoitus ei voi olla vain ennakoitavan edun tavoittelu, vaan sen olisi kyseltävä ihmisen olemassaolon syvintä tarkoitusta. Se merkitsisi Pestalozzin sanoin kannanottoa "humaanin ihmisen kehittymisen puolesta ihmiskunnassa".

\section{Kirjallisuus}

Alanen, Leena 1988. Lapsuus yhteiskunnallisena ilmiönä - yhteiskuntatieteellisen lapsuustutkimuksen näköaloja. Politiikka 3.

Baudrillard, J. 1982. Der symbolische Tausch und der Tod. München.

Beck, U. 1986. Risikogesellschaft. Auf dem Weg in eine andere Moderne. Frankfurt am Main.

Claussen, D (Hrsg.) 1981. Spuren der Befreiung Herbert Marcuse: ein Materialienbuch zur Einführung in sein politisches Denken. Darmstadt/ Neuwied.

Derrida, J. 1985. Apokalypse. Graz/Wien.

Ferry, L. \& Renault, A 1987. Antihumanistisches Denken. Gegen die französischen Meisterphilosophen. München.

Fougault, M., 1974. Die Ordnung den Dinge. Frankfurt am Main.

Freud, S. 1952, Gesammelte Werke. Band 14. Frankfurt am Main.

Friesenbahn, G.J. 1985. Kritische Pädagogik. Horkheimer, Adarno, Fromm, Marcuse. Berlin.

Giesecke, H. 1987. Das Ende der Erziehung. Neue Chancen für Familie und Schule. Stuttgart.

Heydorn, H-J. 1979. Uber den Widerspruch von Bildung und Herrschaft. Frankfurt am Main.

Lyotard, J.F. 1986. Das postmoderne Wissen. Ein Bericht. Graz/Wien.

Marcuse, H. 1968. Der eindimensionale Mensch. Neuwerd/Berlin.

Marcuse, H. 1968. Psychoanalyse und Politik. Frankfurt am Main.

Matthies, J. 1988. Kriittisiä huomautuksia yliopistojen kurrikularisoitumisesta. Kasvatus 3.

Orwell, G. "1980." 1984. Frankfurt am Main.

Salonen, Toivo, 1987. Sivistys, yliopisto ja valtio. Politiikka 1987.

Skinner, B.F. 1973. Jenseits von Freiheit und Fürde. Reinbeck/Hamburg.

Zahn, L 1981. Herbert Marcuse: die Utopie der glücklichen Vernunft. Teoksessa Speck, J. (Hrsg), Grundprobleme der grossen Philosophen. Göttingen.

Käännös:

Aila-Leena Matthies 


\section{AIKUISKASVATUS \\ The Finnish Journal of Adult Education \\ Vol. 9,1/89 \\ ISSN 0358-6197 \\ Summary}

suspect that an individual student is no longer perceived as a subject; instead, that student is treated as an object as a consequence subordinated to techno-economic interests, for instance.

The second part of the article is an attempt by the author to show, with the writings of Marcuse as the basis, the consequences of the materialistic conception of students and people in general in education systems and educational sciences. The article looks at the concept of single dimensionality in the light of a few examples. Finally, the author analyses Marcuse's thought on pedagogy applying it to the present day reality.

Matthies, Jürgen 1989. Sovereignty to be the goal of education?

- In the first part of the article, the author deals with the question of the extent to which modern educational science has, by way of certain research orientations, changed into an utilitarian instrumentology. There is reason to 